\title{
LA PROBLEMATIZACIÓN DEL DISCURSO EN TEXTOS DE MARIO VARGAS LLOSA Y RICARDO DOMÉNECH
}

\author{
ENRIQUE PUPO-WALKER \\ Vanderbilt University
}

Acaso para disipar de entrada expectativas erróneas me parece útil indicar que mis observaciones sobre los textos que he de comentar no proponen una crónica infortunada sobre el tema agobiante de las influencias literarias. No sería necesario constatar las relaciones, por cierto muy íntimas, que existen entre la narrativa española e hispanoamericana de nuestros días. Lo que pretendo, más bien, es elucidar, con la mayor brevedad, el singular proceso de creación que determina la existencia misma y las características sugestivas de dos textos; textos al parecer muy disímiles pero que en realidad no lo son. $\mathrm{Me}$ refiero, concretamente, a La tía Julia y el escribidor de Mario Vargas Llosa, y al relato de Ricardo Doménech titulado "La agonía del General Franco proyectándose en el espejo de enfrente y vista por una generación"; narración ésa que forma parte de su libro Figuraciones.

Al examinar los textos a que me he referido, quisiera destacar, en primer término, la composición un tanto excepcional de ambas narraciones y también el significado cultural que asume la problematización misma del discurso literario; problematización motivada, a mi parecer, por dos razones fundamentales. La primera sería, el afán del escritor por esclarecer la vigencia, a veces contradictoria, del referente contextual. Y la segunda emana de una praxis que tiende a configurar el tex to como si éste fuera, a su vez, un sistema autárquico constituido por signos y los rituales codificados de la escritura. Esas preocupaciones que de una manera simultánea y conflictiva subyacen en ambos textos, se perfilan como tópicos de extraordinaria relevancia en la crítica literaria de nuestro tiempo. Lo que acabo de afirmar ahora no es gratuito si se toma en cuenta, que tanto Doménech como Vargas Llosa destacan no sólo como creadores sino además como críticos interesados en los aspectos teóricos de la actividad literaria. Podremos verificar, aunque sea de

\footnotetext{
Importantes estudios corroboran esas preocupaciones de la crítica. Ver: Jean Starobinski, "On the Fundamental Gestures of Criticism", New Literary History, 5 (1974), 491-514; Kazimierz Bartoszynsky, "The Borderlands of Literary Criticism", New Literary History,"(1980), 211-236; Frederic R. Jameson, "The Symbolic Inference: or Kenneth Burke and Ideological Analysis", Critical Inquiry, 4 (1978), 507-524; Grant Webster, The Republic of Letters: A History of Post-War Literary Opinion (Baltimore: The Johns Hopkins University Press, 1979).
} 
paso, que la narrativa de ambos escritores se nutre, más de una vez, del discurso crítico que ellos han producido casi siempre a la par de la creación verbal.

A nadie se le oculta, por otra parte, que esa inquietud, en sí, no es novedosa. La hemos verificado, desde ángulos muy diversos, en El Quijote, en textos célebres de Unamuno, en el teatro de Pirandello y más recientemente en el "living theater"así como en muchos textos memorables de Borges y Cortázar. Creo, sin embargo, que estas dos narraciones de Vargas Llosa y Ricardo Doménech exaltan de una manera casi exacerbada la naturaleza problemática que exhibe la creación literaria y creo, además, que lo hacen no por el mero goce que encierra la actividad ex perimental, sino más bien para llegar, a veces oblicuamente, a conceptualizaciones que abarcan aspectos muy disímiles del contex to cultural que ha servido de marco a las obras de a mbos escritores. El carácter obsesivo de ese empeño lo denuncia sobre todo el epígrafe tortuoso que Vargas Llosa ha tomado de El grafógrafo de Salvador Elizondo y que sirve como apertura a La tía Julia: "Escribo. Escribo que escribo. Mentalmente me veo escribir que escribo y también puedo verme, ver que escribo...." Esas palabras que se pliegan sobre sí mismas son, en varios sentidos, el testimonio inaugural que hace de la escritura el acontecimiento primordial de la narración; a sabiendas, por supuesto, de que en la palabra escrita están cifradas las formas más refinadas del conocimiento. Pero esas palabras aluden a un esfuerzo creativo que pretende escaparse de las secuencias tautológicas y de la entropía misma. Una vez afrontada esa vertiente problemática y reflexiva de la escritura, quisiera detenerme ante el texto de Ricardo Doménech, principalmente porque es el menos conocido de los dos que he de examinar, y también porque la novela de Vargas Llosacomo veremos más adelante - puede contemplarse, desde otra perspectiva, como una amplificación del mismo proceso narrativo que nos comunica el relato que he de resumir ahora.

En muy pocas palabras lo que se narra en el texto de Doménech es el espectáculo suscitado por una charla que se ofrece en un lujoso salón de actos; sólo que el conferencista, obsesionado por las imperfecciones que contiene su propio discurso insiste en repetir la charla, encadenando, sin pausas, frases que gradualmente pierden su significado hasta convertirse en una suerte de letanía hueca. La situación, cada vez más exasperante, y cada vez más ridícula, termina por desconcertar el público. Aturdidos y nerviosos unos entran y otros abandonan el salón para luego regresar; así, desentendiéndose de lo que ocurre y distraídos por las cámaras de la televisión, varios

${ }^{2}$ La tía Julia... (Barcelona: Seix Barral, 1977), p. 10. Las citas subsiguientes indicarán la paginación en el texto. 
espectadores consumen bocadillos y cervezas mientras el conferencista extenuado y tartamudeando, repite una y otra vez su texto aunque deteniéndose para subrayar "con exquisito cuidado" sectores claves de su ponencia. ${ }^{3}$

La dimensión alegórica-por así decirlo-del relato es evidente según lo delata el amplio título de la narración. Pero una lectura centrada en las particularidades del texto nos revelará enseguida que la singularidad de la narración radica más allá de esa leve representación alegórica que toma como su referente obvio la agonía prolongada del General Franco. De hecho, al leer el texto con avidez observaremos que - con un sesgo Kafkiano - - lo que allí se narra, en definitiva, es la liquidación de un discurso unidimensional que tenía su base en las entelequias vacías del franquismo. Y se narra, además, la gestación-entonces apenas iniciada-de un nuevo discurso cultural que se dilata para recuperar casi todas las categorías vigentes del lenguaje. Comprobaremos, por ejemplo, que el narrador integra, a partir de la crisis misma que experimenta el conferencista, formas muy dispares de la actividad linguística. Aparecen allí, como en La tía Julia, los procedimientos veloces de la crónica periodística y televisiva, las cursilerías de la oratoria burguesa, la jerga popular y hasta los gestos amanerados del lenguaje académico. Acaso para corroborar la pluralidad del texto, el narrador deja constancia de sus propósitos al decirnos que "resultaba fácil enunciar el tema de conferencia, pues al ser un tópico que afectaba por igual a las ciencias y a las letras podía ser enunciado, y aún más desarrollado, desde lenguajes diferentes" (p. 24).

Sin que apenas lo notemos, las palabras como tales se van convirtiendo gradualmente en los verdaderos protagonistas de lo que ocurre. La materia del relato es, entonces, un discurso que se va desnudando ante nosotros y que se vale de los vericuetos de la anécdota para cuestionar, en todas las variantes imaginables, su propia naturaleza. Desde ese rico interdicto de la escritura se relata pues la gestación espontánea de un discurso multivalente que en otras épocas le fue negado a los espectadores que asisten a la conferencia, pero que ahora reaparece ante el lector desde la crisis definitiva que dramatiza la persona misma del conferencista. El texto de Doménech revela de esa manera un acto creativo de ruptura desde que el que rechaza el orden punitivo de ot ras épocas y los últimos visos de aquel costumbrismo infeliz que favorecía la censura, y que siempre se acercó a la realidad no para acrecentarla sino más bien para confirmarla en toda su penuria. La narración de Doménech es, en todo caso, el texto, que con sus signos incordiantes, asume un amplio espacio

\footnotetext{
3 "La agonía del General Franco...", en Figuraciones (Santander: Isla de los Ratones, 1977), p. 21. Otras referencias se darán en el texto. He dedicado un estudio más extenso a este relato. Ver "Indicios de una nueva plenitud: el cuento español y un libro de Ricardo Doménech", Insula, 34, No. 390 (1979), 3.
} 
referencial desde el que se esboza una sugestiva relación dialéctica entre la creación literaria y el proceso cultural en marcha.

Al referirme ahora a La tía Julia y el escribidor no intentaré un resumen detallado de la novela. Creo que un ejercicio expositivo de esa índole prolongaría innecesariamente la fase descriptiva de este trabajo. Quiero no obstante ofrecer un esquema, por fugaz que sea, de la organización a que atiene la obra de Vargas Llosa. En La tía Julia se relata una secuencia alternada de sucesos. Los que se narran en los capítulos nones corresponden a la dimensión autobiográfica desde la cual el narrador-protagonista, Varguitas, describe sus conflictos familiares, sus amores y matrimonio con la tía Julia, así como las vicisitudes propias de un escritor joven. En cambio, los capítulos pares documentan la historia imaginaria en torno al boliviano Pedro Camacho; o sea, el exitoso escribidor de radio novelas a quien Varguitas ha conocido, porque él también trabaja redactando noticias, en otra estación de radio. Así quedan superpuestas en la novela dos secuencias episódicas que se complementan y que a su vez quedarán entrelazadas, más de una vez, en el curso de la narración. A primera vista el ámbito indiscreto y sensual en que viven la tía Julia y Varguitas no parece tener mucho en común con la actividad, a veces patética, del escritor que construye, sin cesar, melodramas interminables. Pero en verdad esos planos diversos de la escritura - como también ocurre en el relato de Doménech-llegarán a comportarse como espejos que duplican ad infinitum sus propias imágenes.

De hecho la narración de Vargas Llosa establecerá, desde el ejercicio sutil de la parodia, vínculos muy dispares entre la escritura de Varguitas y la de Pedro Camacho. E inevitablemente es así porque en la construcción de la novela la memoria que recuerda hechos concretos de un pasado verificable-o sea la de Varguitas - es también la memoria que inventa, como bien lo señaló José Miguel Oviedo.4

De manera muy evidente, es la confesión autobiográfica la que inaugura el proceso narrativo en La tia Julia; pero advertiremos que ese enunciado que alude minuciosamente al pasado de Mario Vargas Llosa, admite un proceso de sucesivos desdoblamientos internos porque, si bien se ve, sus confesiones son, a la postre, la vivencia siempre desconcertante del escritor hispanoamericano que Vargas Llosa, como crítico, nos ha relatado más de una vez; 5 excepto que esa crónica, autorizada por los resortes del discurso historicista,

\footnotetext{
4 "La tia Julia y' el escribidor, or the Coded Self-Portrait", en Vargas Llosa: A Collection of Critical Essays, ed. de Charles Rossman and A. W. Friedman (Austin: University of Texas Press, 1978).

5 Algunas formulaciones primordiales de Vargas Llosa se ofrecen en su trabajo: "Social Commitment and the Latin American Writer", World Literature Today, 52, No. 1 (1978), 6-14.
} 
sólo alcanzará su plenitud expresiva y documental en los registros propiamente dichos de la ficción. Esa vertiente paradójica que señalo resalta en los pasajes brevísimos que citaré a continuación; en ellos se funden, de una manera casi vertiginosa, el dato autobiográfico, las fantasías arquetípicas del escritor hispanoamericano y la reflexión velada en torno al arte literario: "Nos sentamos-explica Varguitas-y estuvimos conversando cerca de dos horas. Le conté toda mi vida no la pasada sino lo que tendría en el futuro, cuando viviera en París y fuera escritor. Le dije que quería escribir desde que había leído por primera vez a Alejandro Dumas, y que desde entonces soñaba con viajar a Francia y vivir en una buhardilla..."(p. 159).

Podremos observar, al mismo tiempo, que esos desdoblamientos internos del discurso a que acabo de aludir, se perciben, sólo que de otro modo, en el sector de la obra que corres ponde al mundo Ped ro Camacho. Escritor éste que es, como Varguitas, ente histórico y creación imaginaria, pero a quien conoceremos a través de una relación biográfica que nos transmite el propio Varguitas. Para corroborarlo bastarían algunos pasajes que esbozan rápidamente la imagen trágico-cómica de Camacho: o sea la del hombre que vive hundido en la creación de una literatura atada al acontecer aberrado que denota el incesto, la violación y otras desviaciones de la conducta humana. Pero irónicamente la vida de Camacho excluye toda vivencia erótica según él mismo lo confirmará: "¿Cree Vd. que es posible hacer lo que hago si las mujeres se tragaran mi energía?..¿Cree que se pueden producir hijos e historias al mismo tiempo? ¿Qué puede uno inventar o imaginar si se vive bajo la amenaza de la sífilis? La mujer y el arte son excluyentes mi amigo. En cada vagina está enterrado un artista. Reproducirse, ¿qué gracia tiene eso? No lo hacen los perros, las arañas, los gatos. Hay que ser originales amigo"(p. 193).

No obstante, esa distancia que al parecer media entre el escribidor de radio novelas y los textos que él produce, se hace cada vez más tenue. Sobre todo cuand o el mismo Ca macho llega a confesar: “„Por qué no voy a tener derecho, para con substanciarme con personajes de mi propiedad, o parecerme a ellos? ¿Quién me prohibe tener mientras los escribo, sus narices, sus pelos y sus levitas?"(p. 164). Además, conviene observar que la identidad de Camacho se desvirtúa un tanto al hacerse eco de las inquietudes del crítico literarioVargas Llosa - que le asedia repetidamente desde los intersticios mismos de la narración: “¿Pero qué cosa es el realismo señores, el tan mentado realismo qué cosa es? ¿Qué mejor manera de hacer arte realista que identificándose materialmente con la realidad?"'(p. 164). Excepto, claro está, que esa realidad a la que Camacho alude, de una manera descabellada, es, en definitiva, la de su propia imaginación. Este hecho, como tal, adquiere en la novela una importancia inusitada porque, en la práctica, las radio novelas de Camacho pasan a ser su relato autobiográfico; relato que en definitiva-como también 
le ocurre al conferencista de Doménech-le lleva hasta los umbrales mismos de la demencia.

En La tía Julia la circularidad conflictiva de la narración, llega a borrar los límites que existen entre el rela to au tobiográfico y la biografía como tal. Y en un plano, quizá aún más significativo, se desvanecen, por igual, las supuestas dicotomías entre la relación histórica o testimonial y el enunciado propio de la ficción. En última instancia la única certidumbre posible en los textos de Vargas Llosa y Doménech no ha de conseguirse, pues, en el prestigioso "querer decir" de la narración histórica o en otras complicidades ilusorias entre la escritura y el mundo de los objetos. En todo caso lo que se insinúa como el referente más genuino será capacidad interpretativa de un relator que aparece dispuesto a fundir ese bazar casi alucinante de tex tos que ingresan de una manera, al parecer-caprichosa, en su discurso para dialogar atropelladamente en la interioridad misma de la estructura narrativa. Concebida así, la razón de ser de la obra conduce a la invención de una actividad crítica que convierte al discurso en material narrable. Y no estaría de más subrayar al mismo tiempo que esa rica proyección interior es, a propósito, la que predomina en dos importantes novelas nortea mericanas de nuestros días. Me refiero, específicamente, a The Ghost Writer (1979) de Phillip Roth y Sophie's Choice de William Styron (1979).

En fina sintonía con el acontecer literario de su tiempo, los textos de Vargas Llosa y Doménech asimilan, desde un voraz esfuerzo creativo, los convencionalismos desiguales de la novela rosa, las evocaciones sentimentales del bolero y formas de la crónica ficcionalizada; formas que remiten, por ejemplo, obras muy conocidas de Truman Capote y Norman Mailer; y todo ello atado, más de una vez, con los hilos frágiles de partes informativos que identificaremos como las formas menos memorables de la escritura. Estamos, entonces, ante dos creaciones literarias que parecen desvirtuar los contornos propios de un género dado para alcanzar las formas más dinámicas y dispares del proceso cultural que las envuelve. $Y$ hay tal vez en esas dos narraciones el rechazo implícito de la postura que ha llevado al intelectual a interesarse sólo por las formas cultas o bien por las manifestaciones básicas del folklore: postura ésa que desprecia, o por lo menos omite, la inmensa zona media del arte popular que canta y lee la gran mayoría. En fin de cuentas esas aperturas de la creación literaria, si se quiere, representan, en términos retóricos, una conceptualización novedosa de la verosimiltud narrativa. Pero, más allá de toda consideración formalista, esa manera de escribir expresa también la disyuntiva-que con frecuencia experimenta el narrador hoy-cuando los convencionalismos literarios y el enunciado engañoso de la narración histórica no le bastan para resolver la ontología precaria de su texto o su propia relación con el mundo casi delirante en que le ha tocado vivir. 